\title{
Sistem Informasi Akuntansi Simpan Pinjam Pada Sinar Kalimantan Dengan Metode Pengembangan Waterfall
}

\author{
Nanda Diaz Arizona ${ }^{1}$, Ety Susilowati ${ }^{2}$
}

\section{Info Artikel}

Diterima Desember, 18, 2020

Revisi Januari, 18, 2021

Terbit Maret, 30, 2021

\section{Keywords:}

Design

AccountingInformation System

Saving and Loans

Financial Report

\begin{abstract}
PT)
Sinar Kalimantan Cooperative is a community service cooperative in savings and loans. Based on the analysis that has been done, the Sinar Kalimantan Cooperative still recaps each per each cash-in and cash-out data transactions that come from notes and then copy them to Ms. Excel to be used as financial statements. Processing data like this requires effort and a long time, errors in data processing that have an impact on the quality of information in financial statements. Therefore, the purpose of writing this Final Project is to design and build a web-based savings and loan accounting information system at the Sinar Kalimantan Cooperative using the waterfall model as a software development method consisting of analysis of software requirements, design, program code creation and testing. Data collection techniques used consisted of observation, interviews and literature study. This system is built to provide facilities for two users, namely the Chairman and the Cashier. Chairman can manage employee (user) data, access loan reports, loan list reports, installment reports, savings reports, general journal reports, general ledger reports, balance sheet reports, cash receipts reports, cash disbursements reports and cash flow report. The cashier can manage account data, customer data, deposit data, deposit withdrawal data, loan data, installment data and expense (cost) data and access loan reports, loan list reports, installment reports and savings reports. The savings and loan accounting information system that was built is expected to help improve the performance of savings and loan data processing at the Sinar Kalimantan Cooperative.
\end{abstract}

\section{Identitas Penulis:}

Nanda Diaz Arizona ${ }^{1}$, Ety Susilowati ${ }^{2}$,

Universitas Bina Sarana Informatika Program Studi Sistem Informasi Akuntansi Kampus Pontianak

Jalan Abdurrahman Saleh no. 18 A Pontianak

Email: nanda.ndz@bsi.ac.id ${ }^{1}$, etyputry11@gmail.com ${ }^{2}$

\section{PENDAHULUAN}

Koperasi merupakan suatu badan usaha yang keanggotaannya mencakup masyarakat setempat yang mengajukan pinjaman untuk modal usaha. Seiring keadaan ekonomi sekarang yang tidak stabil, masyarakat tidak bisa hanya mengandalkan gaji sementara ekonomi yang semakin meningkat, oleh karena itu didirikanlah Koperasi sebagai solusi dalam pemecahan masalah keuangan masyarakat [1].

Komputer sebagai alat bantu sudah digunakan dalam berbagai aktivitas, terutama dalam proses administrasi bisnis perusahaan. Komputer dapat menyimpan data, mengolah data dan memberikan informasi yang dibutuhkan dengan cepat dan akurat. Permasalahan penggunaan sarana kertas sebagai media pengolahan data menjadi suatu yang penting untuk diperhatikan dimana penggunaan kertas rentan akan terjadinya kehilangan data dan memakan banyak tempat untuk penyimpanan data. Permasalahan tersebut dapat diatasi oleh suatu aplikasi yang terintegrasi dengan basis data. Biaya operasional yang dikeluarkan juga lebih rendah apabila dihitung dalam skala tahunan dan dapat mengefektifkan jumlah tenaga kerja yang dimiliki [2].

Koperasi Sinar Kalimantan merupakan sebuah koperasi simpan pinjam yang keanggotaannya mencakup masyarakat setempat yang mengajukan pinjaman untuk modal usaha. Koperasi Sinar Kalimantan didirikan sebagai solusi untuk membantu masyarakat dalam memecahkan masalah keuangan. Dalam menjalankan tugas pokoknya, Koperasi Sinar Kalimantan saat ini masih menggunakan teknik konvensional yaitu 
pencatatan menggunakan alat tulis dan kertas-kertas dan kalkulator untuk mengelola data transaksi peminjaman anggota. Hal ini tentu berdampak pada lamanya proses layanan anggota, proses rekapitulasi transaksi simpan pinjam harian, serta rentan terjadinya ketidakakuratan dan kehilangan data. Setiap transaksi simpan pinjam ditulis langsung buku besar. Apabila terjadi kesalahan pada pencatatan di buku besar, maka akan sangat berpengaruh kepada laporan secara keseluruhan dan merugikan ke dua belah pihak, yaitu anggota dan pihak Koperasi. Laporan-laporan yang dihasilkan juga tidak memenuhi kaidah standar akuntansi keuangan (SAK).

\section{METODE}

\subsection{Metode Pengumpulan Data}

Untuk mengumpulkan data-data yang berkaitan dengan sistem simpan pinjam pada Koperasi Sinar Kalimantan, penulis menggunakan teknik pengumpulan data. Adapun teknik pengumpulan data yang digunakan, terdiri dari :

\section{Pengamatan (Observation)}

Pengamatan langsung terhadap objek yang diteliti di lapangan pada saat melakukan Praktik Kerja Lapangan. Pengamatan langsung ke kantor tersebut untuk melihat proses kegiatannya seperti pemesanan barang, penerimaan barang yang telah dipesan oleh pihak kantor sampai pelaporan pengeluaran kas belanja bulanan. Sehingga mendapatkan informasi yang diinginkan untuk menganalisa proses pencatatan pengeluaran kas belanja bulanan yang dilakukan. Pengamatan langsung dilakukan di Ruangan Administrasi Sekretariatan Daerah Kabupaten Kubu Raya.

2. Wawancara (interview)

Penulis melakukan suatu metode tanya jawab mengenai kegiatan yang berhubungan dengan kantor khususnya kegiatan belanja bulanan dengan bagian bendahara yaitu bapak Fitriadi di Kantor Sekretariat Daerah Pemerintah Kabupaten Kubu Raya. Yang dihasilkan dari wawancara adalah kami menerima data untuk di analisa yang berupa surat pemesanan, surat pengajuan harga, dan kwitansi menerima barang.

3. Studi Pustaka

Selain observasi dan Wawancara, penulis juga melakukan tinjauan pustaka untuk melengkapi data-data yang diperlukan.

\subsection{Metode Pengembangan Software}

Metode pengembangan software bertujuan untuk mengembangkan sistem dan memberikan panduan untuk menyukseskan proyek pengembangan sistem melalui tahapan-tahapan tertentu. Model dari metode pengembangan software yang digunakan adalah model air terjun (waterfall). Model waterfall merupakan salah satu metode pengembangan perangkat lunak menyediakan pendekatan alur hidup perangkat lunak secara sekuensial atau terurut dimulai dari analisa, desain, pengkodean, pengujian, dan pemeliharaan [3].

Tahapan-tahapan dari model air terjun diuraikan sebagai berikut:

1. Analisis Kebutuhan Perangkat Lunak

Proses pengumpulan kebutuhan dilakukan secara intensif untuk mespesifikasikan kebutuhan perangkat lunak agar dapat dipahami perangkat lunak seperti apa yang dibutuhkan oleh user. Analisa kebutuhan perangkat lunak menguraikan tentang kebutuhan fungsional dan kebutuhan non-fungsional yang bersumber dari hasil observasi, wawancara dan dokumen yang di dapat.

2. Desain

Dalam tahapan desain ini, penulis membuat rancangan basis data yang dimodelkan ke dalam entity relationship diagram (ERD) dan logical record structure (LRS) serta spesifikasi file. Berdasarkan hasil analisa, penulis juga memodelkan rancangan sistem menggunakan unified modeling language (UML) untuk memvisualisasikan rancangan, yang terdiri dari use case diagram, activity diagram, sequence diagram dan deployment diagram.

3. Pembuatan Kode Program

Dalam tahapan ini, penulis mengimplementasikan desain yang telah dibuat menjadi sebuah sistem informasi akuntansi. Sistem informasi akuntansi simpan pinjam berbasis web ini dibuat dengan hypertext preprocessor (PHP) dan hypertext markup language (HTML) sebagai bahasa pemrograman. Tampilan atau konten aplikasi agar lebih menarik dibuat dengan cascading style sheet (CSS), bootstraps, javascript dan jQuery. Web editor yang digunakan untuk membuat aplikasi adalah Sublime Text 3. Aplikasi basis data yang digunakan yaitu MySQL dengan bahasa structured query language (SQL) untuk mengelola basis data. Paket aplikasi xampp server atau apache digunakan sebagai web server.

4. Pengujian

Pengujian fokus pada perangkat lunak secara dari segi lojik dan fungsional dan memastikan bahwa semua bagian sudah diuji. Hal ini dilakukan untuk meminimalisir kesalahan (error) dan memastikan keluaran yang 
dihasilkan sesuai dengan yang diinginkan. Teknik pengujian yang digunakan adalah metode black box testing untuk menguji kebutuhan fungsional sistem yang telah dibuat.

5. Pendukung (support) atau pemeliharaan (maintenance)

Support atau pemeliharaan sistem dapat dilakukan apabila aplikasi yang dibuat tidak sesuai dengan yang diharapkan atau melakukan perubahan jika merasa ada sesuatu yang masih ingin dikembangkan pada aplikasi.

\section{HASIL}

\subsection{Proses Bisnis Sistem Berjalan}

Pada bagian ini penulis akan menguraikan tentang proses sistem berjalan mengenai simpan pinjam pada Koperasi Sinar Kalimantan, bertujuan untuk mengetahui lebih jelas bagaimana kerja dari suatu sistem dan mengetahui masalah yang dihadapi. Adapun tahapan dari proses sistem berjalan yang diterapkan oleh Koperasi Sinar Kalimantan di Kabupaten Kubu Raya, diuraikan sebagai berikut:

1. Prosedur Registrasi Calon Anggota dan Survey

Mantri menjelaskan aturan atau syarat-syarat untuk menjadi anggota kepada calon anggota Koperasi Sinar Kalimantan. Untuk menjadi anggota, calon anggota harus menyerahkan Kartu Tanda Penduduk (KTP), Kartu Keluarga (KK) dan Kartu Indonesia Sehat (KIS) atau Kartu Badan Penyelengggara Jaminan Sosial Kesehatan (BPJS Kesehatan). Mantri akan memeriksa data-data yang diberikan oleh calon anggota dan melakukan survey untuk memastikan data-data yang diterima oleh calon anggota terjamin keasliannya. Apabila data-data tersebut asli dan sesuai dengan hasil survey, maka Mantri akan memberitahukan kepada calon anggota tersebut bahwa proses peminjaman dapat dilanjutkan atau diterima. Mantri akan menyerahkan KTP, KK dan KIS atau Kartu BPJS Kesehatan calon anggota ini kepada Kasir dan diarsipkan. Apabila datadata yang tersebut tidak asli atau tidak sesuai dengan hasil survey, maka Mantri akan memberitahukan kepada calon anggota tersebut bahwa proses peminjamannya ditolak dan mengembalikan KTP, KK dan KIS atau Kartu BPJS Kesehatan.

2. Prosedur Peminjaman

Anggota mendatangi Koperasi Sinar Kalimantan dan dilayani oleh Kasir. Kasir menjelaskan serangkaian aturan peminjaman kepada Anggota yang mengajukan pinjaman (besar pinjaman, potongan untuk simpanan dan aturan pembayaran angsuran). Kasir menyerahkan formulir peminjaman (Promise Koperasi) untuk diisi oleh Anggota. Anggota mengisi formulir peminjaman (Promise Koperasi). Kasir mengarsipkan formulir peminjaman (Promise Koperasi) yang telah diisi, kemudian Kasir mencatat ke dalam buku pinjaman dan menyerahkan dana pinjaman beserta kwitansi peminjaman kepada anggota yang mengajukan pinjaman.

3. Prosedur Pembayaran Angsuran

Mantri melakukan penagihan langsung (door to door) untuk setiap anggota yang melakukan pinjaman. Jika anggota berada di rumah dan dapat membayar angsuran, maka Mantri akan menerima pembayaran angsuran tersebut dan mencatat ke dalam buku tagihan (dengan bukti bahwa anggota menandatangani buku tagihan). Apabila anggota tidak dapat ditemui atau tidak dapat membayar angsuran, maka Mantri akan melakukan penagihan di hari berikutnya. Mantri menyerahkan uang yang diterima dari proses penagihan dan salinan dari data-data angsuran yang tercatat di dalam buku tagihan kepada Kasir. Kasir menyimpan uang-uang yang diterima dan mengarsipkan salinan dari data-data angsuran yang tercatat di dalam buku tagihan. Kasir akan menyerahkan KTP, KK dan KIS atau Kartu BPJS Kesehatan kepada Mantri untuk dikembalikan anggota yang telah membayar seluruh angsuran. Apabila angsuran belum lunas, maka Mantri akan tetap melakukan penagihan setiap harinya.

4. Prosedur Pengolahan Laporan

Pada akhir bulan, Kasir mengumpulkan data-data yang berkaitan (Promise Koperasi dan data angsuran dari buku tagihan) untuk dijadikan sebagai laporan keanggotaan dan laporan keuangan untuk diserahkan kepada Pimpinan. Pimpinan memeriksa laporan-laporan tersebut, apabila disetujui, maka Pimpinan akan menandatangani atau memberi pengesahan di laporan tersebut kemudian disimpan ke dalam arsip bulanan, apabila tidak disetujui (terdapat kesalahan dalam pembuatan laporan), maka Kasir harus membuat laporan kembali.

\subsection{Activity Diagram}

\subsubsection{Activity Diagram Sistem Berjalan}

Setelah melakukan riset atau penelitian pada Koperasi Sinar Kalimantan mengenai simpan pinjam, dapat diketahui gambaran dan proses bisnis dari simpan pinjam. Proses bisnis yang sudah diketahui ini, 
kemudian dimodelkan ke dalam bentuk activity diagram. Adapun hasil pemodelan untuk setiap prosedur atau tahapan pada proses bisnis sistem menjadi activity diagram dapat dilihat pada gambar berikut ini.

1. Activity Diagram Registrasi Calon Anggota dan Survey

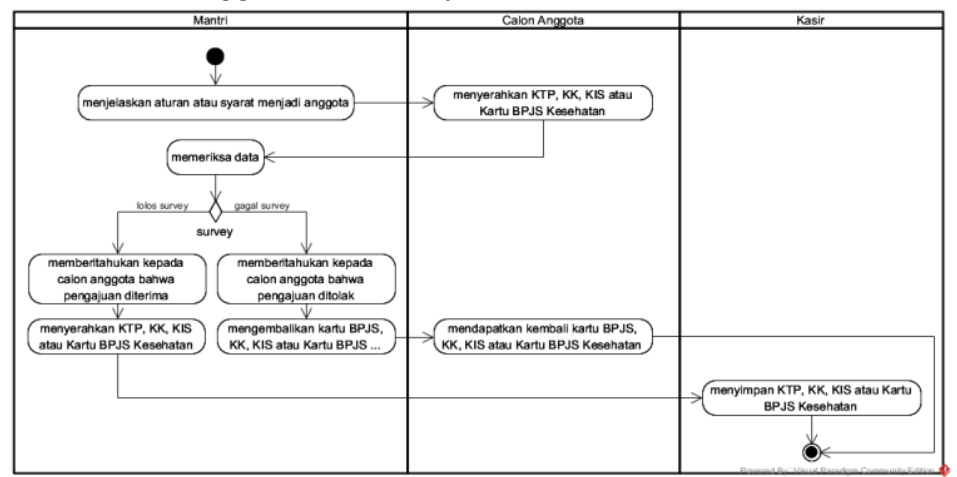

Sumber : Hasil Perancangan (2020)

Gambar 1. Activity Diagram Registrasi Calon Anggota dan Survey

Mantri menjelaskan aturan atau syarat-syarat untuk menjadi anggota kepada calon anggota Koperasi Sinar Kalimantan. Untuk menjadi anggota, calon anggota harus menyerahkan Kartu Tanda Penduduk (KTP), Kartu Keluarga (KK) dan Kartu Indonesia Sehat (KIS) atau Kartu Badan Penyelengggara Jaminan Sosial Kesehatan (BPJS Kesehatan). Mantri akan memeriksa data-data yang diberikan oleh calon anggota dan melakukan survey untuk memastikan data-data yang diterima oleh calon anggota terjamin keasliannya. Apabila data-data tersebut asli dan sesuai dengan hasil survey, maka Mantri akan memberitahukan kepada calon anggota tersebut bahwa proses peminjaman dapat dilanjutkan atau diterima. Mantri akan menyerahkan KTP, KK dan KIS atau Kartu BPJS Kesehatan calon anggota ini kepada Kasir dan diarsipkan. Apabila datadata yang tersebut tidak asli atau tidak sesuai dengan hasil survey, maka Mantri akan memberitahukan kepada calon anggota tersebut bahwa proses peminjamannya ditolak dan mengembalikan KTP, KK dan KIS atau Kartu BPJS Kesehatan.

2. Activity Diagram Prosedur Peminjaman

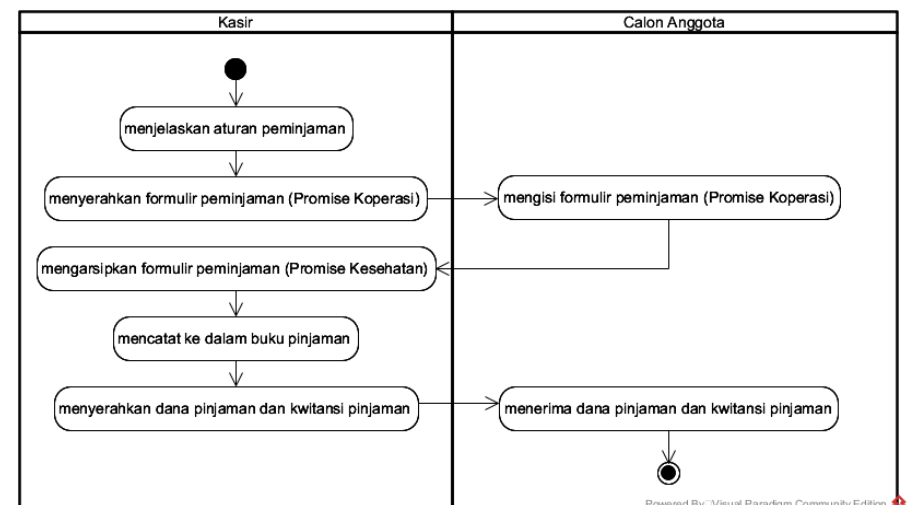

Sumber : Hasil Perancangan (2020)

Gambar 2. Activity Diagram Prosedur Peminjaman

Anggota mendatangi Koperasi Sinar Kalimantan dan dilayani oleh Kasir. Kasir menjelaskan serangkaian aturan peminjaman kepada Anggota yang mengajukan pinjaman (besar pinjaman, potongan untuk simpanan dan aturan pembayaran angsuran). Kasir menyerahkan formulir peminjaman (Promise Koperasi) untuk diisi oleh Anggota. Anggota mengisi formulir peminjaman (Promise Koperasi). Kasir mengarsipkan formulir peminjaman (Promise Koperasi) yang telah diisi, kemudian Kasir mencatat ke dalam buku pinjaman dan menyerahkan dana pinjaman beserta kwitansi peminjaman kepada anggota yang mengajukan pinjaman.

\subsubsection{Analisa Kebutuhan Perangkat Lunak}

Koperasi Sinar Kalimantan sangat membutuhkan sebuah software atau aplikasi yang bisa membantu dalam pengerjaan pengolahan data simpan pinjam. Oleh sebab itu, dalam penjelasan ini penulis ingin mengajukan rancangan sistem usulan yang dapat membantu Koperasi Sinar Kalimantan dalam mengolah transaksi simpan pinjam. 


\subsubsection{Tahapan Analisis}

Kebutuhan kebutuhan user untuk sistem informasi akuntansi simpan pinjam pada Koperasi Sinar Kalimantan memerlukan beberapa form untuk interface user. Keamanan juga yang diperlukan untuk penggunaan sistem usulan sehingga nantinya keamanan data dapat terjaga. Berdasarkan prosedur rancangan sistem tersebut, maka akan dibutuhkan beberapa form untuk mengolah data agar menghasilkan laporan simpan pinjam pada Koperasi Sinar Kalimantan. Berikut menu yang dibutuhkan dalam tampilan sistem informasi akuntansi simpan pinjam :

\section{A. Pimpinan}

A1. Login

A3. Mengelola Data Karyawan

A4. Mengakses Laporan

1) Laporan Pinjaman

2) Laporan Daftar Pinjaman Anggota

3) Laporan Angsuran

4) Laporan Simpanan

5) Laporan Jurnal Umum

6) Laporan Buku Besar

7) Laporan Neraca Saldo

8) Laporan Kas Masuk

9) Laporan Kas Keluar

10) Laporan Arus Kas

A5. Logout

B. Kasir

A1. Login

A3. Mengelola Data Akun

A4. Mengelola Data Anggota

A5. Mengelola Transaksi Penerimaan

1) ata Simpanan

2) Data Angsuran

A6. Mengelola Transaksi Pengeluaran

1) Data Ambil Simpanan

2) Data Pinjaman

3) Data Biaya

A7. Mengakses Laporan

1) Laporan Pinjaman

2) Laporan Daftar Pinjaman Anggota

3) Laporan Angsuran

4) Laporan Simpanan

A8. Logout

\subsubsection{Use Case Diagram}

Dari dari analisa kebutuhan yang telah diuraikan, penulis dapat menggambarkan fasilitas atau rancangan sistem sesuai kebutuhan pengguna. Bentuk rancangan sistem untuk sistem informasi akuntansi simpan pinjam pada Koperasi Sinar Kalimantan dalam bentuk use case diagram, sebagai berikut: 


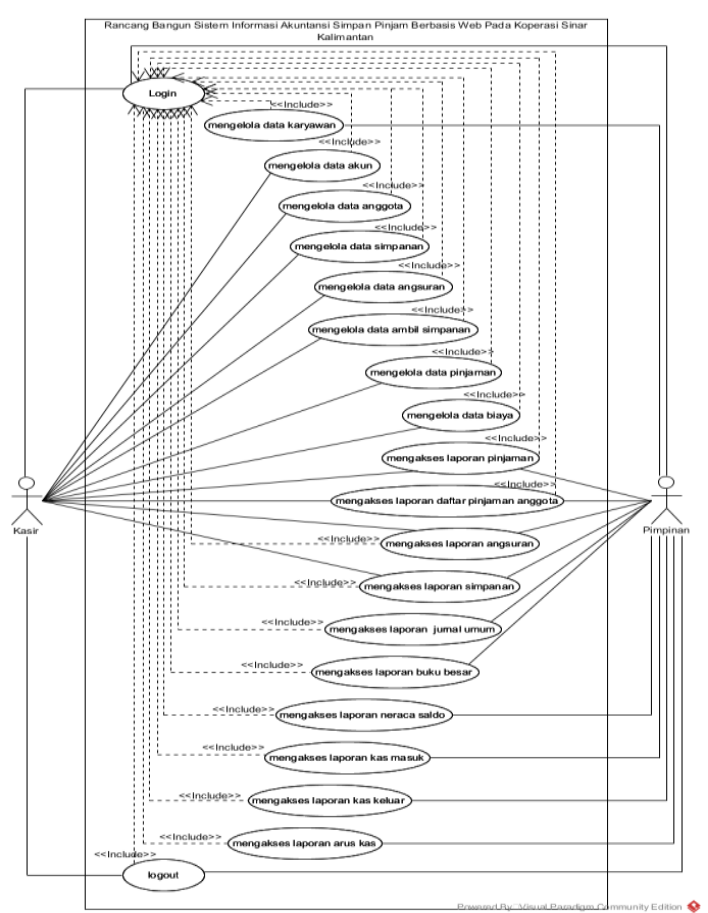

Sumber : Hasil Perancangan (2020)

Gambar 3. Usecase Diagram Sistem Informasi Akuntansi Simpan Pinjam

Berdasarkan gambar 3, sistem yang dirancang ini terdiri dari dua (2) level akses, yaitu Pimpinan dan Kasir. Pimpinan dapat mengelola data master: yaitu data karyawan, mengakses laporan yang terdiri dari: laporan pinjaman, laporan daftar pinjaman anggota, laporan angsuran, laporan simpanan, laporan jurnal umum, laporan buku besar, laporan neraca saldo, laporan kas masuk, laporan kas keluar dan laporan arus kas. Kasir dapat mengelola data master yang terdiri: data anggota dan data akun, transaksi penerimaan yang terdiri: data simpanan dan angsuran, transaksi penerimaan terdiri: data ambil simpanan, pinjaman dan biaya, mengakses laporan yang terdiri dari laporan pinjaman, laporan daftar pinjaman anggota, laporan angsuran dan laporan simpanan.

\subsubsection{Desain}

\subsubsection{Entity Relationship Diagram (ERD)}

Entity relationship diagram (ERD) digunakan sebagai teknik pemodelan rancangan basis data untuk menjelaskan hubungan antar entitas di dalam basis data berdasarkan objek-objek yang mempunyai hubungan antar relasi. Berikut ini adalah bentuk dari entity relationship diagram (ERD) untuk rancangan basis data dari sistem informasi simpan pinjam pada Koperasi Sinar Kalimantan.

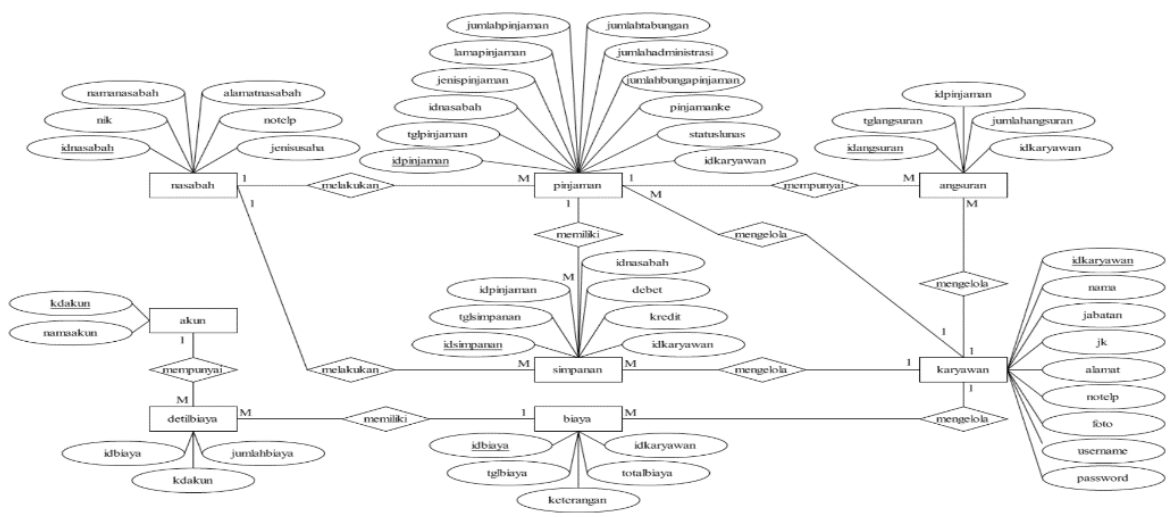

Sumber : Hasil Perancangan (2020)

Gambar 4 Entity Relationship Diagram (ERD) 
Pada gambar 4. dapat dijelaskan bahwa rancangan basis data yang digambarkan menjadi entity relationship diagram (ERD) dari sistem informasi simpan pinjam pada Koperasi Sinar Kalimantan terdiri dari dari delapan (8) entitas, yaitu karyawan, akun, nasabah, pinjaman, simpanan, angsuran, biaya dan detil biaya. Entitas karyawan berfungsi untuk menyimpan data pengguna aplikasi. Entitas akun berfungsi untuk menyimpan data nama ayat jurnal atau nama akun. Entitas nasabah berfungsi untuk menyimpan data nasabah atau anggota koperasi. Entitas pinjaman berfungsi untuk menyimpan data pinjaman dari nasabah. Entitas simpanan berfungsi untuk menyimpan data simpanan nasabah atau anggota. Entitas angsuran berfungsi untuk menyimpan data angsuran dari nasabah atau anggota. Entitas biaya berfungsi untuk menyimpan data biaya atau pengeluaran. Entitas detil biaya berfungsi untuk menyimpan rincian dari biaya atau pengeluaran. Setiap entitas ini terhubung dan memiliki relasi serta derajat relasi.

\subsubsection{Logical Record Structure (LRS)}

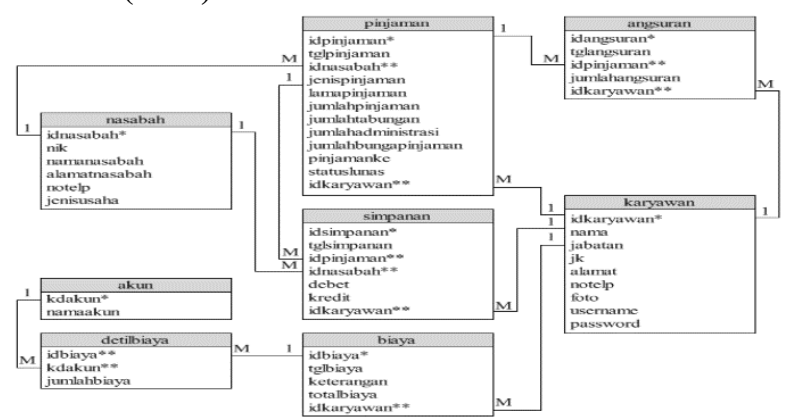

Sumber : Hasil Perancangan (2020)

Gambar 5. Logical Record Structure (LRS)

Pada gambar 5. dapat dijelaskan bahwa rancangan basis data yang digambarkan menjadi logical record structure (LRS) dari sistem informasi simpan pinjam pada Koperasi Sinar Kalimantan terdiri dari dari delapan (8) entitas, yaitu karyawan, akun, nasabah, pinjaman, simpanan, angsuran, biaya dan detil biaya. Entitas karyawan berfungsi untuk menyimpan data pengguna aplikasi. Entitas akun berfungsi untuk menyimpan data nama ayat jurnal atau nama akun. Entitas nasabah berfungsi untuk menyimpan data nasabah atau anggota koperasi. Entitas pinjaman berfungsi untuk menyimpan data pinjaman dari nasabah. Entitas simpanan berfungsi untuk menyimpan data simpanan nasabah atau anggota. Entitas angsuran berfungsi untuk menyimpan data angsuran dari nasabah atau anggota. Entitas biaya berfungsi untuk menyimpan data biaya atau pengeluaran. Entitas detil biaya berfungsi untuk menyimpan rincian dari biaya atau pengeluaran. Setiap entitas ini terhubung dan memiliki relasi serta derajat relasi.

\subsubsection{User Interface}

\subsubsection{User Interface login}

Pengguna memiliki hak yang sama yaitu dapat melihat halaman login. Berikut ini adalah halaman login aplikasi berbasis website :

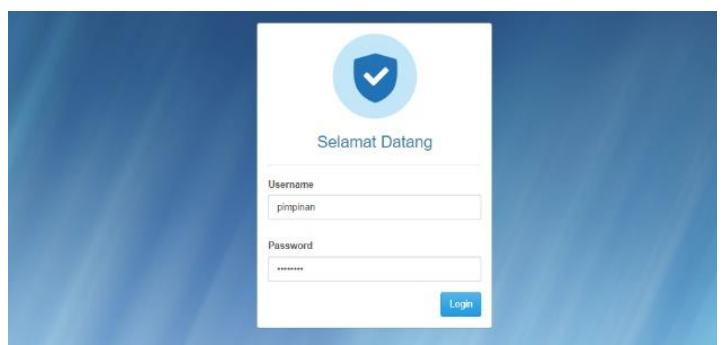

Sumber : Hasil Perancangan (2020)

\section{Gambar 6. User Interface login}

Gambar 6 berikut adalah user interface login rancangan sistem pada Koperasi Sinar Kalimantan dimana login disini terdapat username dan password yang harus di isi, setelah diisi dan masuk berhasil maka sistem akan menampilkan menu utama.

3.2.4.2 User Interface Beranda

Koperasi Sinar Kalimantan dimana menu utama disini terdapat menu pengolahan data karyawan dan menu pengaksesan laporan. Pada menu utama ini terdapat tombol keluar jika ingin keluar dari sistem.: 
Sumber : Hasil Perancangan (2020)

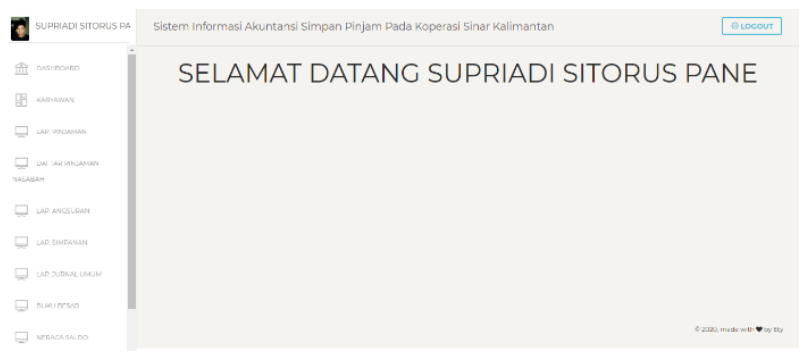

Gambar 7. User Interface Beranda

3.2.4.3 User Interface Menu Simpanan
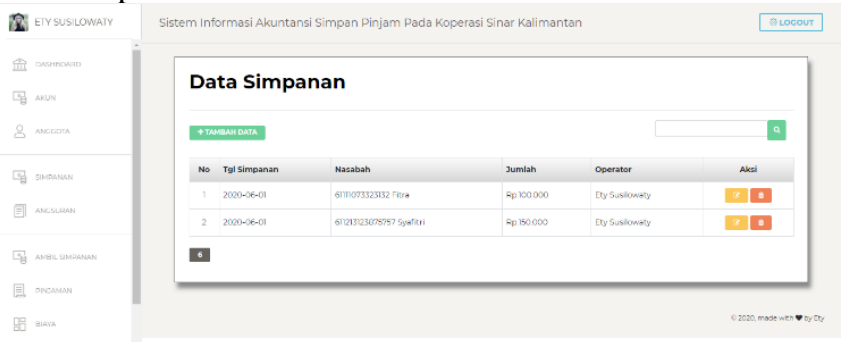

Sumber : Hasil Perancangan (2020)

Gambar 8. User Interface Menu Simpanan

Gambar 8. berikut adalah user interface menu simpanan rancangan sistem pada Koperasi Sinar Kalimantan dimana menu akun disini terdapat menu pengolahan data tambah, edit, cari dan hapus data simpanan.

3.2.4.4 User Interfase Menu Tambah Simpanan

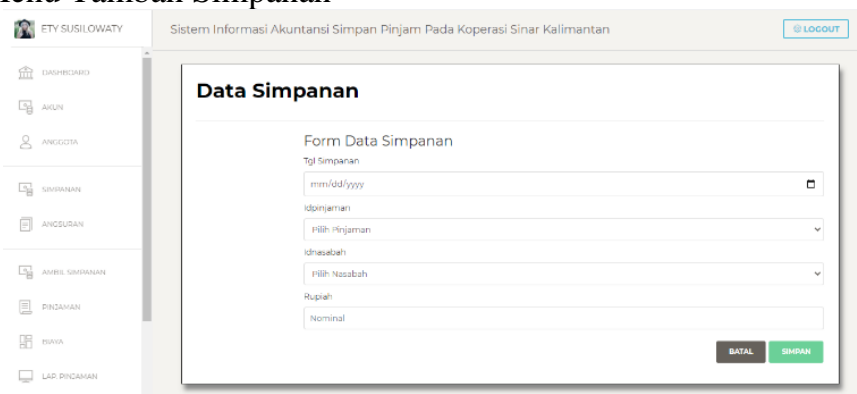

Sumber : Hasil Perancangan (2020)

\section{Gambar 9. User Interface Menu Pengelolaan Data Pengeluaran Kas}

Gambar 9. adalah user interface menu tambah simpanan rancangan sistem pada Koperasi Sinar Kalimantan dimana menu tambah simpanan merupakan bagian menu dari menu simpanan yang berfungsi untuk menambah data simpanan baru.

3.2.2.5 User Interfase Menu Pinjaman

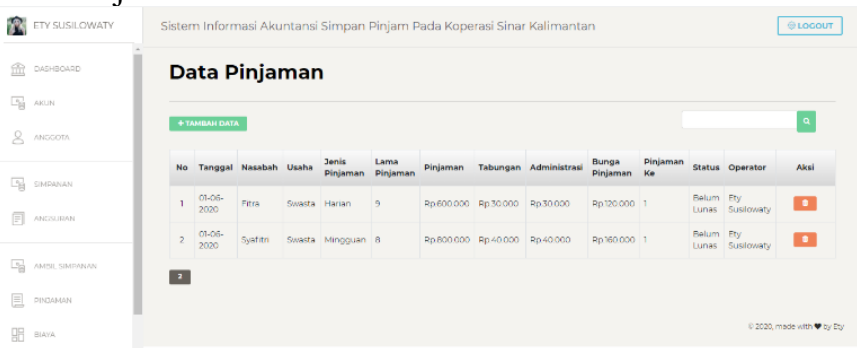

Sumber : Hasil Perancangan (2020)

Gambar 9. User Interface Menu Pengelolaan Data Pengeluaran Kas

Gambar 9. berikut adalah user interface menu pinjaman rancangan sistem pada Koperasi Sinar Kalimantan dimana menu pinjaman disini terdapat menu pengolahan data tambah, edit, cari dan hapus data pinjaman. 


\subsubsection{Black Box Testing}

Pengujian dilakukan untuk menguji kelayakan fungsional dari sistem informasi akuntansi simpan pinjam berbasis web pada Koperasi Sinar Kalimantan. Teknik yang digunakan untuk pengujian ini adalah menggunakan teknik black box testing. Pengujian yang dilakukan hanya mengamati hasil eksekusi dan memeriksa kelayakan fungsional dari sistem informasi akuntansi simpan pinjam berbasis web pada Koperasi Sinar Kalimantan yang telah dibuat.

3.2.5.1 Black Box Login

Tabel 1

Black Box Testing Halaman Login

\begin{tabular}{|c|c|c|c|c|c|}
\hline No. & $\begin{array}{c}\text { Skenario } \\
\text { pengujian }\end{array}$ & Test case & Hasil yang diharapkan & $\begin{array}{c}\text { Hasil } \\
\text { pengujian }\end{array}$ & Kesimpulan \\
\hline 1. & $\begin{array}{l}\text { Jika salah satu } \\
\text { kolom } \\
\text { dikosongkan }\end{array}$ & $\begin{array}{l}\text { username: } \\
\text { (kosong) }\end{array}$ & $\begin{array}{l}\text { aplikasi menolak akses } \\
\text { dan muncul pesan } \\
\text { "username atau } \\
\text { password anda salah, } \\
\text { silahkan coba lagi" }\end{array}$ & $\begin{array}{c}\text { Sesuai } \\
\text { harapan }\end{array}$ & Valid \\
\hline 3. & $\begin{array}{l}\text { Kolom terisi } \\
\text { namun tidak } \\
\text { sesuai (username } \\
\text { dan password) }\end{array}$ & $\begin{array}{c}\text { username: } \\
(111111) \\
\text { password: } \\
(111111)\end{array}$ & $\begin{array}{l}\text { aplikasi menolak akses } \\
\text { dan menampilkan pesan } \\
\text { "username atau } \\
\text { password anda salah, } \\
\text { silahkan coba lagi" }\end{array}$ & $\begin{array}{l}\text { Tidak } \\
\text { Sesuai } \\
\text { Harapn }\end{array}$ & Invalid \\
\hline 4 & $\begin{array}{l}\text { Kolom terisi dan } \\
\text { sesuai (username } \\
\text { dan password } \\
\text { sesuai) }\end{array}$ & $\begin{array}{l}\text { username: } \\
\text { (pimpinan) } \\
\text { password: } \\
\text { (pimpinan) }\end{array}$ & $\begin{array}{c}\text { Aplikasi menerima } \\
\text { akses dan mengantarkan } \\
\text { pengguna ke halaman } \\
\text { utama. }\end{array}$ & $\begin{array}{c}\text { Sesuai } \\
\text { Harapan }\end{array}$ & Valid \\
\hline
\end{tabular}

Sumber : Hasil Perancangan (2020)

3.2.5.1 Black Box Halaman Menu Simpanan

Tabel 2

Black Box Testing Halaman Menu Simpanan

\begin{tabular}{cccccc}
\hline No. & $\begin{array}{c}\text { Skenario } \\
\text { pengujian }\end{array}$ & Test case & Hasil yang diharapkan & $\begin{array}{c}\text { Hasil } \\
\text { pengujian }\end{array}$ & Kesimpulan \\
\hline 1. Jika semua kolom & semua kolom: & Aplikasi menolak akses \\
di kosongkan & (kosong) & $\begin{array}{c}\text { Sesuai } \\
\text { han menampilkan pesan } \\
\text { "please fill } \text { out this } \\
\text { field" }\end{array}$ & Valid \\
& \multicolumn{4}{c}{ apan } \\
\end{tabular}

\begin{tabular}{cccccc}
\hline 2. & $\begin{array}{c}\text { Jika salah satu } \\
\text { kolom } \\
\text { dikosongkan }\end{array}$ & $\begin{array}{c}\text { tgl simpanan: } \\
\text { (kosong) } \\
\text { kolom lain: } \\
\text { (terisi) }\end{array}$ & $\begin{array}{c}\text { aplikasi menolak akses } \\
\text { dan menampilkan pesan } \\
\text { "please fill out this } \\
\text { field" }\end{array}$ & $\begin{array}{c}\text { Sesuai } \\
\text { harapan }\end{array}$ & Valid \\
\hline 3. & $\begin{array}{c}\text { Jika semua kolom } \\
\text { terisi }\end{array}$ & $\begin{array}{c}\text { semua kolom: } \\
\text { terisi }\end{array}$ & $\begin{array}{c}\text { Aplikasi menerima } \\
\text { akses dan menyimpan } \\
\text { data tersebut }\end{array}$ & $\begin{array}{c}\text { Sesuai } \\
\text { Harapan }\end{array}$ & Valid \\
\hline 4. & Edit data simapan & $\begin{array}{c}\text { Semua kolom } \\
\text { terisi }\end{array}$ & $\begin{array}{c}\text { Aplikasi menerima } \\
\text { akses dan menyimpan } \\
\text { data tersebut }\end{array}$ & $\begin{array}{c}\text { Sesuai } \\
\text { Harapan }\end{array}$ & Valid \\
\hline 5. & $\begin{array}{c}\text { Hapus data } \\
\text { simapan }\end{array}$ & $\begin{array}{c}\text { Pilih data dan } \\
\text { klik hapus }\end{array}$ & $\begin{array}{c}\text { Aplikasi menerima } \\
\text { akses dan menghapus } \\
\text { data tersebut }\end{array}$ & $\begin{array}{c}\text { Sesuai } \\
\text { Harapan }\end{array}$ & Valid \\
\end{tabular}

Sumber : Hasil Perancangan (2020) 


\section{KESIMPULAN}

Dari hasil penelitian yang telah dilakukan, penulis dapat menarik kesimpulan mengenai beberapa kelebihan dari penggunaan program aplikasi, diantaranya:

a. Sistem yang diterapkan oleh Koperasi Sinar Kalimantan untuk pengolahan data simpan pinjam masih menggunakan teknik konvensional yaitu pencatatan menggunakan alat tulis dan kertas-kertas dan kalkulator untuk mengelola data transaksi peminjaman anggota. Sering terjadi kesalahan pada pencatatan di buku besar yang mempengaruhi hasil laporan serta laporan-laporan yang dihasilkan tidak memenuhi kaidah standar akuntansi keuangan (SAK).

b. Sistem yang diterapkan oleh Koperasi Sinar Kalimantan yang dibuat ini menyediakan fasilitas berupa transaksi simpan pinjam khusus koperasi dan menghasilkan laporan-laporan yang sesuai dengan standar akuntansi keuangan. Maka dari itu, sistem informasi akuntansi simpan pinjam diharapkan dapat membantu Koperasi Sinar Kalimantan dalam mengelola data simpan pinjam dan menghasilkan laporanlaporan sesuai dengan standar akuntansi keuangan (SAK).

c. Sistem informasi akuntansi simpan pinjam yang dibuat dengan berbasis web ini menyediakan fitur untuk dua (2) level akses, yaitu pimpinan dan kasir. Pimpinan dapat mengelola data karyawan, mengakses laporan pinjaman, laporan daftar pinjaman nasabah, laporan angsuran, laporan simpanan, laporan jurnal umum, laporan buku besar, laporan neraca saldo, laporan penerimaan kas, laporan pengeluaran kas dan laporan arus kas. Kasir dapat mengelola data akun, data nasabah, data peminjaman, data angsuran, data simpanan, data ambil simpanan, data biaya, mengakses laporan pinjaman, laporan daftar pinjaman nasabah, laporan angsuran dan laporan simpanan.

\section{UCAPAN TERIMA KASIH}

Penulis menyadari bahwa tanpa bimbingan dan dorongan dari semua pihak, maka jurnal ini tidak akan lancar. Oleh karena itu, pada kesempatan ini penulis ingin menyampaikan terima kasih kepada :

1. Rektor Universitas Bina Sarana Infomatika.

2. Wakil Rektor 1 Bidang Akademik Universitas Bina Sarana Informatika.

3. Dekan Fakultas Teknik dan Infomasi Universitas Bina Sarana Informatika.

4. Ibu Lisnawaty, ST, M.Kom Selaku Ketua Program Studi Sistem Informasi Akuntansi Kampus Kota Pontianak, Fakultas Teknik dan Informasi Universitas Bina Sarana Informatika Kota Pontianak.

5. Bapak Supriadi Sitorus Pane selaku Pimpinan pada Koperasi Sinar Kalimantan.

6. Staf dan karyawan di lingkungan Koperasi Sinar Kalimantan.

7. Ibu Windi Irmayani SE. M.Kom.

8. Rekan-rekan Dosen Universitas Bina Sarana Infomatika PSDKU Pontianak

Serta semua pihak yang telah membantu penulis dalam menyelesaikan jurnal ini yang tidak dapat disebutkan satu persatu.

\section{REFERENSI}

[1] Saputro, M. I., \& Mardiana, T. (2015). Agen Cerdas Untuk Penentuan Kelayakan Pemberian Kredit Koperasi Simpan Pinjam. Teknik Komputer, I(2), 245-252.

[2] Arizona, N. D., Yulia, \& Saputro, R. (2018). Aplikasi Pengolahan Data Penerimaan Dan Pengeluaran Kas. Jurnal PILAR Nusa Mandiri Vol. 14, No. 2 September 2018, 14(2), 253-260.

[3] Sukamto, R. A., \& Shalahuddin, M. (2015). Kolaborasi Rekayasa Perangkat Lunak Terstruktur dan Berorientasi Objek. Bandung: Informatika. 